\title{
Rethinking Leadership Theories
}

\author{
Emmanuel Mango',2 \\ ${ }^{1}$ United States International University-Africa, Nairobi, Kenya \\ ${ }^{2}$ Kome Business Consultants (KomeBC), Nairobi, Kenya \\ Email:mangoimmy@gmail.com
}

How to cite this paper: Mango, E. (2018). Rethinking Leadership Theories. Open Journal of Leadership, 7, 57-88.

https://doi.org/10.4236/oj1.2018.71005

Received: January 17, 2018

Accepted: March 17, 2018

Published: March 20, 2018

Copyright $\odot 2018$ by author and Scientific Research Publishing Inc. This work is licensed under the Creative Commons Attribution International License (CC BY 4.0).

http://creativecommons.org/licenses/by/4.0/

\begin{abstract}
Leadership is governed by over 66 theories which leaves many leaders and leadership scholars searching for an inclusive leadership theory. The existence of too many leadership theories obstructs progressive practice and research of leadership, hence there is need for leadership theory consolidation. This paper is an attempt to integrate leadership theories. The integration efforts are based on representative leadership theories and the review of the wider relevant leadership literature. Initially, the integration was to be built around 66 leadership theories but with further study 44 theories were eliminated to avoid either repetition or miniature issues and it was established that the 22 leadership theories are a good representation of the concepts captured in leadership theories. The review of the 22 leadership theories was enriched with insights from the wider leadership literature. The review and synthesis of leadership theories and the wider relevant leadership literature revealed that leadership is built on six (6) foundational domains, namely: character, characteristics, people practices, institutional practices, context and outcomes (CCPICO). The six domains occasioned the development of an integrative leadership model: ethical and effective leadership (EEL). As a consequence of the EEL model, one, the EEL subdomains are highlighted, two, leadership development based on EEL model is proposed, three, leadership definition that is in line with EEL model is suggested.
\end{abstract}

\section{Keywords}

Leadership Theories, Ethical and Effective Leadership, Character, Characteristics, People Practices, Institutional Practices, Leadership

Outcomes, Context, Follower, Leadership Development

\section{Introduction}

Theories guide research and inform practice through modelling of some aspects of the empirical world (Northouse, 2016; Wright \& McMahan, 1992). 
Well-developed theories are used to solve problems in the real world (Stam, 2007). Despite the centrality of theory to practice and research, the current status of leadership theory is best captured by an ancient Indian story of six blind ("blind" here is used figuratively) men who had never been exposed to an elephant. One day, each of the six men was guided to touch a specific part of the elephant, each of the six men touched a part different from his colleagues. The first one held the trunk, the second one held the tusk, the third one held the ears, the fourth one held the legs, the fifth one held the belly area towards the back and the sixth blind man held the tail.

After all the blind men had touched their respective parts, they were taken aside and asked to define an elephant. The blind man who touched the trunk said, "an elephant is a snake", the blind man who touched the tusk said, "an elephant is a spear", the blind man who touched the ears said, "an elephant is a fan", the blind man who touched the leg said, "an elephant is a pillar", the blind man who touched the belly said, "an elephant is a wall" and finally, the blind man who touched the tail said, "an elephant is a rope". When each blind man had stated his views of what an elephant was, an argument ensued among the blind men, each man insisting that his definition of the elephant was the right one. Each of the blind men promoted one aspect of the elephant as the whole elephant, not that they were wrong, they just did not consider all aspects of the elephant, they did not have the full picture of what an elephant was. Just like each of the blind men had some information about the elephant, many people have some information about leadership but they are yet to interact with the totality of leadership (Northouse, 2016), hence, the existence of many incomplete perspectives on leadership.

Like the six blind men, many leadership scholars never miss an opportunity to promote one leadership perspective as the entire truth about leadership (Kellerman, 2012; Snook, Nohria \& Khurana, 2012). The malaise of promoting one aspect or domain as a whole is often accompanied by neophilic tendencies. Reviewing the extant leadership literature, it is evident that love for new things (in this case, love of new leadership theories) bedevils leadership scholars and practitioners alike, however, the love of new ideas at the expense of the existing ones is not limited to leadership scholars and practitioners. Some scholars and interpreters of knowledge, from diverse fields, once they discover a new perspective, they ridicule the old perspective or even set it aside. For example, when performance management came into existence, performance appraisal was ridiculed, yet in real life, performance management and performance appraisals are inseparable (Armstrong, 2006). With the introduction of modern theories of leadership, like transformational theory some scholars question the soundness older leadership theories like traits theory (Lawler, 2005; Allio, 2012), although the old leadership theories may not tell the whole leadership story, they tell part of it. Each theory offers a unique perspective on leadership which helps us to learn one or more aspects of leadership. However, House \& Aditya (1997) warn that a few leadership theories miss the big picture of leadership because of the over- 
emphasis placed on one aspect at the expense of the other aspects of leadership.

The leadership field is overcrowded with theories. Northouse (2016) has examined 16 theories, Kellerman (2012) asserts there are over 40 leadership theories while Meuser, Gardner, Dinh, Hu, Liden, \& Lord (2016) contend that the number of leadership theories is in the upwards 66. Given the existence of too many theories of leadership, it is difficult to have focused research in the field. The tens of theories in existence violate the principle of parsimony because of the repetitions exhibited in different theories. In light of the challenges posed by the numerous theories in the leadership field, scholars are calling for consolidation of leadership theories. It is high time that we should inject some hygiene the leadership field. The hygiene should take the form of integrating the leadership theories or approaches (Eberly, Johnson, Hernandez \& Avolio, 2013; Meuser et al., 2016; Glynn \& Raffaelli, 2010; Hernandez, Eberly, Avolio \& Johnson, 2011; Dansereau, Seitz, Chiu, Shaughnessy \& Yammarino, 2013; DeRue, Nahrgang, Wellman \& Humphrey, 2011). This paper attempts to bring together the various leadership perspectives in order to tell one whole leadership story.

Leadership is a paradox and like other paradoxes, it needs not be solved but it should be accommodated by accepting that there are many valid ideas and solutions (Handy, 1994). Therefore, the question is why is the author attempting to piece together the various leadership perspectives while humanity is supposed to live with complexities? The idea that leadership theories/approaches can be pieced together despite that scholars disagree on the right leadership approach is in itself a paradox and as such we should also accommodate it. Whereas leadership theories offer numerous viewpoints, they do not contradict each other, they complement each other and it is that very reason that makes it possible to bring the leadership theories together (Silva, 2015; Glynn \& Raffaelli, 2010).

Considerable efforts have been made toward consolidating leadership theories. Meuser et al. (2016) argued that majority if not all leadership theories can coalesce around six focal leadership theories: charismatic theory, transformational theory, leadership and diversity, strategic theory, participative/shared leadership and the trait theory. While this approach integrates 66 leadership theories into six theories, six is still large numbers and also the components of each of the six theories are not clearly spelt out. Hernandez et al. (2011) contend that all leadership theories should be seen from two angles: loci-source(s) of leadership and mechanism-how leadership is transmitted. The loci involves: leaders, context, followers, collectives and dyad while the mechanism involves: traits, behaviour, cognition and affect. This approach is silent on the purpose(s) of leadership. Dansereau et al. (2013) assert that establishing a common thread that cuts across the leadership theories is a good starting point in the effort to integrate leadership theories. They identify self-expansion and boundary conditions, as the common thread, in addition, their effort to show and advocate for an integrating theory that brings leaders and followers together. However, like Hernandez et al. (2011), Dansereau et al. (2013) is silent about the purposes of lea- 
dership and the fact that integration is meant to facilitate leadership serve its purpose.

While recognizing the efforts of other leadership scholars like Meuser et al. (2016), Eberly et al. (2013), Hernandez et al. (2011), Dinh, Lord, Gardner, Meuser, Liden, \& Hu (2014) and Dansereau et al. (2013), towards integrating leadership theories. In this paper, I deconstruct the most representative leadership theories and rebuild them into one theory laced with new insights from the broader leadership literature on followers and context while taking into account parsimony, an all-important principle in theory building. Parsimony is when the theory is able to explain everything known and important about the construct (in this case leadership) with least variables and assumptions.

At the heart of an extensive literature review was a thorough examination of 22 leadership theories as shown in Table A1 in Appendix. The review targeted mainly the theory model (the most practical part of the theory) and in some cases other key defining aspects of the theory. Initially, the study aimed at reviewing the 66 leadership theories as captured in the work of Meuser et al. (2016) but some theories were eliminated because there were much repetitiveness and unnecessary miniature subdivisions. Many theories have propped up that shouldn't be considered as mainstream leadership theories, for example, gender and cultural leadership theories. Such theories are inventions to customize leadership to certain segments (male, female, students and others) of the society. Whereas, looking at leadership from various prisms may serve a certain need, but how far should we go in compartmentalization of leadership? Should we have black leadership and white leadership? I contend that there should be a basic/foundational concept of leadership, which recognizes that leadership occurs in a context, hence, the issues like gender, age, race and organization are contextual issues. Contextual issues explore how the various segments of the society perceive, decode and apply leadership, however, the domestication of leadership cannot stand alone as a complete leadership theory. It ought to work with the basic/foundational leadership concept. Therefore, this paper attempts to establish and consolidate that relationship. Besides the 22 leadership theories reviewed for this paper, the author also examined the current wider leadership literature to establish whether there are aspects of the wider leadership literature that can be tapped for the leadership theory. The study starts with the review of leadership theories as captured in Table A1 in Appendix.

\section{Lessons from the Leadership Theories}

The review of 22 representative leadership theories revealed a higher level of consistency in the themes across the different leadership theories, little if any, contradictions were established, contrary to what some scholars like Dansereau et al. (2013) have suggested. However, the review revealed among other things three key issues, first, much repetition was discovered, and one wonders why too many leadership theories are needed to say the same thing. It is this repetition 
that may lead those who are new to the leadership field to assume that leadership is too wide and confusing, it leaves them asking for the best theory to inform leadership practice. Second, there are plenty of miniature subdivisions of leadership components. The third issue, in the attempt to define one part of the "elephant", the totality of the "elephant" is lost. Leadership is bigger than each individual approach represented by an individual theory. A thorough review of 22 representative leadership theories revealed that leadership theories cover five areas (domains) with a differing degree of details in each domain. The domains are character, characteristics, people practices, institutional practices and outcomes. Table A1 in Appendix shows how the key attributes of each leadership theory in the study are mapped to the five leadership domains.

\subsection{Character}

Different theories have adopted different nomenclature for character, including but not limited to ethics, morals, values and integrity but this paper adopted character to represent the rest. Numerous leadership theories contend that leaders must be people of character (ethical/moral) in order to have the moral authority to influence followers to achieve goals that serve the greater good. Character is inevitable in organizations. When organizational leadership embodies values like humility, stewardship and integrity, it does not only give leaders the moral authority to demand the same from their followers but it also shows the followers how to practice those values. Theories that place character at the center of leadership include great man, trait, authentic leadership, level-five leadership, adaptive leadership, charismatic leadership, transformational leadership, servant, strategic and ethical leadership (Carlyle, 1841; Stogdill, 1948, 1974; George, 2003; Collins, 2001; Heifetz, 1994; Weber, 1947; Bass, 1985; Greenleaf, 1970; Ireland \& Hitt, 2005; Mihelič, Lipičnik \& Tekavčič, 2010).

Less than half of the leadership theories in Table A1 are explicit about the importance and the place of character in leadership. Despite the lack of centrality of character in the majority of the leadership theories, the few theories that address themselves on the place of character in leadership are clear that lack of it in leadership is the main problems bedevilling leadership today (Mihelič, Lipičnik \& Tekavčič, 2010; George, 2003). It is my contention that the main and direct challenge to the place of character in leadership is the push to move leadership away from the leader coupled with demonizing of traits. It may be true that teams or institutions can be moral/ethical agents, but this is only possible if people in those teams or institutions are moral agents themselves. In most cases when institutions fail the moral/ethical test, the failure can be traced back to an individual's or individuals' unethical acts.

\subsection{Characteristics}

The characteristics domain describes the leader's qualities: it portrays the inherent attributes of a leader. Apart from the trait theory which views leader's characteristics as the basis of any leadership, other leadership theories discuss lea- 
dership characteristics among other important elements of leadership. However, it is easy to identify characteristics from those theories. The main focus of leader's characteristics is on "what the leaders are or what they have, especially but not entirely what they were born with" not "what they can do". Leadership characteristics cover the traits like intelligence; personality like extraversion; emotional intelligence like self-awareness and other characteristics like being ambitious, persistent and courageous. Possession of these characteristics enables one perform their leadership role better and those who don't have the leadership characteristics, the opposite is true (Carlyle, 1841; Stogdill, 1948, 1974; Zaleznik \& Kets de Vries, 1975; George, 2003; Weber, 1947; Greenleaf, 1970; Hambrick \& Mason, 1984).

This domain is not keen on followers (it must have been assumed that people with great leadership traits will automatically command a following), it is largely about the leader and her fabulous characteristics. The domain is largely silent on leadership outcomes, success has been assumed to be inevitable for great men and persons with leadership traits. The conundrum is that Hitler and Mandela have a number of traits in common (confidence, commitment, motivational, focused, persuasive and decisiveness. Therein lies a problem, the antithesis of leadership and the saint of leadership cannot be that similar. There must be something about leadership that is not captured in this domain.

\subsection{People Practices}

The majority (over 80 percent) of the leadership theories in Table A1 describe what leaders do with and for the people in order to influence them to achieve the desired organizational goals. It is all about what leaders do not what they are. The argument advanced by this domain is that if leaders diligently carry out people practices they will equip, empower and inspire the followers to perform their roles, hence the organizational performance. This domain is ever growing since many practitioners and scholars are searching for "better" ways to lead people. Practitioners like Miller (2012) has helped Chic-fil-A develop a set of practices abbreviated as SERVE, while scholars like Kouzes \& Posner (2012) have developed a set of practices called 'the leadership challenges: how to make extraordinary things happen in organizations'. The numerous people practices may be an indication that scholars haven't agreed on a single set of practices to influence the followers to achieve the desired outcomes. Some theories see the influencing process as leading by example (charismatic and authentic leader) while others advocate for use of reward and punishment (transaction) to influence. The domain is keen on people development because of the consensus that is building around, "leaders are made not just born". Other people practices revealed in the review include but not limited to monitoring and evaluating performance, selecting and positioning people, supporting, directing and involving people in decision making (Zaleznik \& Kets de Vries, 1975; Luthans \& Avolio, 2003; Katz, 1955; Blake \& Mouton, 1964; Hersey \& Blanchard, 1977; Fiedler, 1967; Vroom \& Yetton, 1973; Heifetz, 1994; Bass, Avolio, Jung, \& Berson, 2003; 
House \& Mitchell, 1974; Bass, 1985; Greenleaf, 1970; Ireland \& Hitt, 2005).

The domain is keen on making followers better by working through and/or with followers while less emphasis is paid on improving institutions as a whole. Most theories that predominantly focus on this domain are silent of leaders' characteristics, but keen analysis of these theories reveal the underlying leadership characteristics, for example, in path-goal theory the leader who is supportive is assumed to be friendly and approachable. Therefore, it accurate to assert that leaders who advance theories that largely favour people practices, themselves possess certain leadership characteristics, although they do not mention it.

\subsection{Institutional Practices}

Institutional practices highlight leaders' undertakings to expand the organization's capabilities to attain its goals. Whereas a few theories in this domain cover diverse area of institutional development, a majority of the institutional practices are geared towards clarifying the organizational goals and directions. Leaders seek ways to develop efficient organizational structure, craft and clarify the organizational goals, establish systems, policies, processes, procedures and monitor their implementation (Luthans \& Avolio, 2003; Katz, 1955; Blake \& Mouton, 1964; Hersey \& Blanchard, 1977; Vroom \& Yetton, 1973; Heifetz, 1994; Ireland \& Hitt, 2005; Hambrick \& Mason, 1984).

Besides people practices, institutional practices have received much attention. Leadership theories that are strong in this area are also strong in people practices and that is it. There is little discussion of the other elements of leadership.

\subsection{Outcomes}

Why does leadership exist and what should leadership achieve? This question alludes to the fact that leadership should serve a certain purpose, it is that purpose that should be captured in the outcome domain. Only 6 out of 22 theories reviewed in this paper have attempted to deal with leadership outcomes. Some of the leadership outcomes outlined in leadership theories include but is not limited to goals, performance beyond expectation, effective strategic leadership, profitability and team performance (Zaleznik \& Kets de Vries, 1975; House \& Mitchell, 1974; Bass, 1985; Ireland \& Hitt, 2005; Hambrick \& Mason, 1984; Hill, 2016).

Even the very few theories that address the issue of leadership outcomes they do not offer sufficient details on the same. Transformational theory refers to leadership outcomes as "performance beyond expectation" while path-goal theory refers to outcomes as a goal. It is not clear whether the outcome in the two cases the same. There is need to define what is expected of leadership or what leadership aiming at. The domain is not conclusive on what results are being sought by leadership, hence, the verdict about the purpose of leadership is not out yet.

The current leadership literature indicates that leadership is broader than what is captured in the extant leadership theories. First, the theories are not 
emphatic and conclusive in some domains like leadership outcomes and characters. Second, theories are largely silent on other domains like context. The next section will make emphasizes in areas lacking in substance and also include areas that leadership literature demands that they should be considered in leadership theory.

\section{Insights from the Wider Leadership Literature}

Certain aspects of leadership like character, followers, context and leadership outcomes are not accorded the emphasis they deserve in the leadership theories, Rothlin \& Haghirian (2013); House \& Aditya (1997); Kellerman (2012, 2015); Miller (2012), hence, this section will cover those aspects in light of the wider leadership literature and with the view of incorporating them in leadership theory.

\subsection{The Character}

Character gains prominence and heightened public interest when organizational scandals are exposed (Novicevic, Zikic, Martin, Humphreys, \& Roberts, 2013). Given the importance of character/morals, the public should be watchful throughout, not just when scandals are exposed, to ensure that organizations are run by people of character. Leaders with moral identity rarely make decisions that sharply contrast their identity. Moral identity leads to responsible leadership. Leaders with moral identity meet internal and external stakeholders' needs, they are good role model to the followers, they are visionary and they are change agents who lead with integrity. Character predicts leader's performance, influences followers' behaviour and impacts team performance (Gomienchi, 2004). Leidner (2017) asserts that George Washington, more than all his brilliant compatriots, was chosen to lead the American Continental Army because he was a man of impeccable moral integrity. Character above anything else should inform/determine the choice of a leader. If character/ethics is removed from the leadership equation you end up with an effective Hitler.

Companies are alive to the value of character, hence, they search for leaders with character to lead the organizations, and the main hindrance in this quest is how to evaluate character. However, Chic-fil-A stops at nothing in its quest for a person of character, Miller (2012), argues that the organization deploy the iceberg principle in its recruitment, where character accounts for 85 percent while skills account for 15 percent. Chic-fil-A may conduct up to 20 interviews before they hire a single person because they hire character and train for skills.

Leader's actions, unlike a private individual's actions, impact many people, hence, the leader ought to act ethically (Flanigan, 2017). Safty (2003) faults the culture that is entrenched in many organizations that only focuses on making money for the investors, hence, managers seek and receive tips mainly on how to be productive. Morals are of least of concern, hence the prevalence of corporate scandals. The desired and achieved organizational goals and the process of achieving them must be ethical. It is leaders' work to help organizations through 
moral conundrums since they are moral agents who are not only concerned with organizational immediate performance but also with its legacy (Thompson, 2010). Leaders act on behalf of others' interest, hence the need for them to be trustworthy (Thompson, 2010). Burns (1978) was alive to the fact that leadership is built on morality, a leader is a moral actor, who serves the interest of public good. Moral leadership is about meeting followers' authentic needs and aspirations and keeping values in the process. It is not only possible to make business decision through a moral prism but it is also possible to have business success. It is not either/or, it is both. Moral leadership "combines business expertise with the determination to bring the moral point of view to bear on all business decisions. Its authority derives as much from moral authenticity as from business acumen" (Becker, 2013: p. 20).

Rothlin \& Haghirian (2013) contend that the current approach to business ethics (centred on the regulatory and legal framework) is not sufficient in solving the ethical challenges of the dynamic world. There is need to expand the business ethics framework to include virtue ethics. Virtue ethics is based on an individual's character. Virtues go beyond individual proper behaviour (as many people look at virtue). For example, philanthropic activities should not be viewed as the hallmark of virtue ethics, they are merely symptoms/fruits of the same.

Rothlin \& Haghirian (2013) argue character traits like truthfulness, reliability, and honesty should be developed in and among individuals to solve the ethical challenges faced by organizations in the current dynamic world. However, inculcating character is not an easy thing. Drucker (2004) argues that character is not an outside job, it is developed inside, hence, most of the leadership development programs do not develop character.

\subsection{The Followers}

Burns (1978) argues that a transforming relationship is not built on raw power, it is built on mutual stimulation and elevation between the leader and follower. The leader must know her followers, understand their goals and quality (knowledge, sophistication and willingness to act on their desire) in order to determine how to work with them for the mutual benefit of the organization. In situations where the followers are more knowledgeable than the leader, it is imperative that the followers take the lead and vice versa. Drucker (2004) points out that Andrew Carnegie wanted to be remembered for his ability to put into his service more able men than he was himself. Able employees who are well-equipped and given space to work not only do they do their jobs well but they also participate in making leadership more effective.

Followers are a crucial part of the leadership equation (Carsten, Uhl-Bien, West, Patera, \& McGregor, 2010). Followers play many roles but two stand out: co-workers and co-leaders. As co-workers, followers like leaders are employed or volunteer to carry out organizational activities. They have a role by the virtue of 
their position to fulfil, needless to say, that if they fail to perform their role the organization's performance will suffer. In the same breath the leader, like the follower, is assigned or assigns herself some activities to perform and failure to perform those activities will also negatively impact organization's performance. In most cases followers do not fully take over the roles of the leader, they may offer advice to the leader in areas where they more versed than the leader or they may participate in leadership in order to bring in a different perspective to find answers to adaptive challenges (Heifetz, 1994). The overall responsibility, authority and accountability still lie with the leader, hence, the followers are just participating in the same way a leader participates by giving her views on matters in different departments. The leader's participation in those departments does not earn her the right to be a specialist in departments, so it shouldn't earn the followers special recognition. The co-workers (followers) should have no special place in leadership theory beyond what is reserved for participation and involvement of team members (House \& Mitchell, 1974; Hersey \& Blanchard, 1977). This is just coworking, relying on each other's strength after all both the leader and followers are working towards similar objectives.

Secondly, the follower as a co-leader, here the follower is performing in the role of a leader as a peer (Carsten et al., 2010). The responsibility, authority and accountability must be equally shared. At that moment the follower is a leader because a leader is not a specific person, it is any person performing the role of a leader. Leaders (the persons performing the role of leadership) are dispensable but not the role of a leader or leadership (Choi \& Schnurr, 2014). For example, in self-directed teams, there is no designated leader but there is leadership; the team has to have direction, the team has to be equipped and inspired, monitored, evaluated and eventually it has met its objectives (Hill, 2016). A follower may perform those roles, but it should not be lost to us that at that point the follower is a leader. As result, there is no need to have a special mention of the follower in the leadership theory, there is no distinction between a follower and a leader at that point.

All agents (loci) or sources of leadership like leaders, followers or collection of persons, context dyads (Hernandez et al., 2011), must be governed by the six leadership domains proposed in this paper. To the extent that followers are co-leading, they ought to be judged by the same standards as leaders. They must have the character and characteristics of a leader. They must have the knowledge, ability and willingness to carry out people practices and institutional practices and have the understanding of the context in which the organization is operating and in which leadership is being exercised. Finally, the followers performing the role of the leader must understand and fulfil the purpose of leadership to all the stakeholders (employees, shareholders and community) in the organization. When the followers perform leader's role it means that they share responsibility, authority and accountability with the leader and in case of a failure or success, the pain or joy must be shared as well. The unfortunate aspect is that the louder and conspicuous voices calling for followers' involvement in lea- 
dership are not so loud and unequivocal on where and who lies with the leadership authority, overall responsibility and accountability or what is or should be the level of followers' involvement (Kellerman, 2008, 2012; Eberly et al., 2013; Snook et al., 2012).

If it isn't a problem for accountancy being accountant centric, it shouldn't be a problem for leadership to be leader-centric. We should not forget that leaders are hired to lead, just like an accountant is hired to keep books of accounts. It is not unusual for an accountant to be at the centre of accounting function in an organization. So it should not be unusual for leaders to lead. I agree, leaders need not be heroes (Manz \& Sims, 1991), they just have to be professionals and do their work just like other professions do their work. Many employees request funds from the organization when they are travelling for work, while on the trip they keep records, including receipts, on return to the office they account for the money advanced to them. It is accountant's work to account for organization's resources particularly, financial resources and keep records yet when any employee travels he or she, in part, performs the work of an accountant. Should the non-account (the employee who had travelled) claim to be recognized as an accountant, should she or he file a complaint that accountancy is accountant centric?

In advancing self-leadership, team leadership, distributed leadership and other forms of follower-driven leadership, we must be careful not to come from the bad situation where leaders used to delegate responsibility without delegating authority to a worse situation where we delegate authority without responsibility. Even when both responsibility and authority are delegated where is accountability in this equation? The followers may give advice, initiate undertakings but if things go wrong as they often do, they are not held accountable. If the overall accountability remains with the leaders, then both leaders and followers are important but distinct. The custodian of leadership is the leader, just like other professionals are custodians of their respective dockets. The ultimate responsibility of leadership lies with the leader. In the process of reclaiming leadership from dictators and other bad leaders, we must not forget that leaders serve a purpose, leaders are not identical to followers. The fact that leaders work with followers and through them doesn't take away followers' importance. Designating some people as leaders do not diminish the fact followers have a part to play just as leaders have a role to play. Leaders like other professionals (accountants, engineers and doctors) only thrive with the participation and involvement of other people in the organization.

\subsection{The Context}

Kellerman (2015) refers to context as the "setting within which work [including leadership] gets done". Ethical and effective leadership is made of the context, the conviction and being credible (Leavy, 2003). Ethical and effective leaders understand the context in which leadership happens and how to utilize the context for maximum organizational outcomes. The context is the backdrop on 
which leadership happens, it is the theatre in which the drama of leadership occurs. Weather leaders emerge because of the prevailing situations or not, leaders must overcome and/or use their context to achieve the set goals. Like politics, all leadership is local. Context affects leadership outcomes, hence, it affects organizational performance. It is not only context that affects leadership, leadership also affects the context (Bredeson, Klar \& Johansson, 2011; House \& Aditya, 1997). Leadership context affects leadership impact (Leavy, 2003). Context affects the effectiveness of leadership (Blackmore, 2011). Despite that leadership manifest itself in the organizational context, the study of leadership for the longest time has never given context the preeminence it deserves (House \& Aditya, 1997). Hartley \& Benington (2010) argue that in sectors like health care there is little to report about with regard to the all-important interaction between leaders and internal and external organizational context.

In searching for a leader, the focus is not on the best leadership theory of the future, but on the current and future environment in which leadership will happen, hence, finding a leader better suited for both environments. Mikkelsen \& Jarche (2015) assert that leaders in today's dynamic world must be able to see around the corner and provide the way out of the minefield. Leaders can only see around the corner if they can read the organizational context.

The assumption that a leader can thrive in any environment (social, demographic, economic, geographical and regulatory conditions) can only be true if such a leader develops context intelligence to excel in the different context. Churchill may not have excelled in post-war Germany just like Konrad Adenauer may not have been successful in leading the Britons in the Second World War, unless a great person, in a great country (time, circumstances and place) has a great issue to solve, they will never become great leaders. It is when the three meet that the end results are a great leader (Nixon, 1982). Context is never a peripheral issue, it is at the heart of successful leadership undertaking. Leaders should have a thorough understanding of the environment and how it affects their organization in its pursuit to achieve its objectives. A leader should have a rare understanding of the problem and how to solve it. Gandhi understood that the best way to solve Indians' oppression by Britons was to solve the problem in a way that does not create victims and victors (Akella, 2009). He did not only understand the current and past environment but he understood the future environment.

Thriving in different context demands higher learning agility. Leader's learning agility transforms the leaders from being effective in a fixed environment to thrive in numerous context. Seeking to understand the environment will among other things propel organizations to become learning organizations. Learning is at the centre of mastering and benefiting from context because context is dynamic. The ability to understand and predict the environment for the present and the future is enormous advantage for leaders (Hartley \& Benington, 2010). The only assurance leaders have for tomorrow's success is not having all the knowledge there is, but the ability to predict and/or create tomorrow. The ulti- 
mate weapon in leaders' arsenal against a dynamic tomorrow is when leaders learn how to learn in the ever-changing context. Petrie (2014) argues that one of the four trends of the future of leadership development is that leadership development must go beyond the individual leader to embrace the context since the context enables leaders to emerge and thrive. It is incomplete to study leadership and followership devoid of context, Morris (2014) argues that if a study of leadership with/or followership is not anchored in context then it should not be taken seriously.

Leadership discourse and practices should go beyond internal situation analysis to consider the broader context in which leadership occurs and leadership affects (Kellerman, 2015). Situation is more localized, more internal looking while context is both inward and outward looking (Janiesch, 2010). Leaders must understand the internal and external environment in order to be in a position to define the organization's place in the world. Leaders should learn and embrace what strategists have known for years: context or environment is central to leadership success. Leaders must consider mapping out how to win in the changing environment. Leaders must seek to understand the past, the present and the future organizational context by analyzing the internal and external environment so that they can make and execute intelligent decisions. Table A2 in Appendix, provides tools and areas to conduct a comprehensive and effective context analysis. The context levels (internal, local, national or global) of analysis may differ depending on the markets the organization serves or intend to serve (Hartley \& Benington, 2010).

Given the importance of context and the argument that leadership happens in the context as captured above, hence context is a moderating variable in the leadership relationship since it is not a direct driver of the leadership outcomes.

\subsection{The Outcomes}

Some leadership theories, for example, behavioural and trait theories do not explicitly show how the leadership behaviour or traits affect leadership outcomes (Northouse, 2016). Why are leaders hired and why are some leaders sacked? Some scholars say leaders influence people who in turn make things happen (Maxwell, 1998; Gardner, 2011; Huang \& Paterson, 2017). Let us take a second that leaders influence followers, but the question begs: why do leaders influence followers? There is a reason why President Bush was blamed for poor handling of Hurricane Katrina's aftermath, (Kellner, 2007), yet the president does not literally run the Federal Emergency Management Agency. There is a reason why Lee Kuan Yew was credited with raising Singapore from a third world country to a first world country in one generation (Yew, 2000). Outcome is the ultimate reason for the existence of leadership and why leaders are hired and some sacked. The argument that leadership is an influence is not only ambiguous since influence can be negative or positive, Kellerman (2004), but it is also narrow, leadership is more than that, leaders' work is to deliver results for all organizational benefactors. Since organizations exist to enable both internal and ex- 
ternal stakeholders to thrive. This is not to say that the activities that leaders undertake or their character and characteristic are not important, but it is to say that the activities that leaders undertake and who they are, both are revealed in leadership outcomes. Russell \& Underwood (2016) question why outcomes are placed at the periphery of leadership, as such, they argue that it is time to rethink what is leadership success. Drucker (1996) argues that whatever else leaders do, they must produce results. Leadership is judged on the results.

Given that leaders achieve results through people, numerous leadership theories advocate for outcomes that lead to better people and better working environment, House \& Mitchell (1974); Kouzes \& Posner (2012), this is one step in the right direction but there is more to leadership, and it is author's contention that leaders and leadership is hired for wholesome organizational success. First, it is leadership's role to ensure that employees are fulfilled and equipped (Bass, 1985). Second, leadership should ensure that shareholders sustainably benefit from their investment (Madison, Holt, Kellermanns, \& Ranft, 2016). Third, the organization does not exist in a vacuum, hence, leadership must ensure that the organization participate in community activities (Greenleaf, 1970). Whereas team's fulfilment is extremely important if the organization is bankrupt, the leaders will be sacked and organization auctioned. In pursuing leadership results it is not either of the three outcome areas, it is all or none.

Two false dichotomies have been erected on leaders' path. The first false dichotomy is that leaders cannot fulfil both the shareholders' and employees' needs at the same time (Miller, 2012). The truths is both the shareholders and employees can be happy at the same time. The second dichotomy is that leaders cannot achieve results and do it ethically (Rothlin \& Haghirian, 2013). Ethical and effective leaders can achieve results and achieve them ethically. Whereas the argument that the leader's work is to take care of the people, then people will take care of the results is plausible, since without the people the leader cannot achieve the result by themselves, but I contend that taking care of people is necessary but not a sufficient condition for a successful organization. Therefore, the primary focus of leadership should be in the three result areas.

Safty (2003) posits that leadership is the ability to achieve results. Therefore, it is accurate to say that leadership is conditional on results. In this regard, no one can be called or call herself a leader without tangible results. Leadership is earned, it is a series of intended results. It is safe to say that not all people who achieve results are leaders but it is even wiser to say that people who achieve nothing cannot be leaders. Grint (2005: p. 23) argue that in the final analysis of things, people who are potential leaders but have accomplished nothing do not count as leaders, "without results there is little support for leadership". It is my contention that very few people will be sympathetic to a leader who argues that he has put in place a clear strategic plan and that he has provided all the support that the team needs yet the team is not producing the required results. This because leadership is judged by it results not effort. One day the people of Kenya made this very clear to their president in 2016, the president hosted an an- 
ti-corruption conference at state house where he went on to complain that he provide everything his team wanted to fight corruption but nothing to show for that the provision (Uhuru, 2016). Many people responded that the president cannot be a crybaby, he is the leader, and he should eradicate corruption or resign. It is results that justify leadership.

\section{Ethical and Effective Leadership}

This section covers the results of the review of the representative leadership theories and wider relevant leadership literature, under subsections: ethical and effective leadership model and EEL subdomains. In addition, the section also covers the consequences of EEL model on leadership development and leadership definition.

\subsection{The Ethical and Effective Leadership (EEL) Model}

A review and synthesis of leadership theories and the wider leadership literature (imperatives of leadership) revealed that impactful leadership is both ethical and effective, leading to ethical and effective leadership (EEL) model. The EEL model is made up of character, characteristics, people practices, institutional practices, context and outcomes. Figure A1 in Appendix shows the EEL model for leadership practitioners.

Five propositions can be derived from both leadership theory and the wider leadership literature.

Proposition 1: The character of the leader (or loci playing the role of the leader) predicts the organizational outcomes.

Proposition 2: The characteristics of the leader (or loci playing the role of the leader) predict the organizational outcomes.

Proposition 3: People practices espoused by the leader (or loci playing the role of the leader) predict the organizational outcomes.

Proposition 4: Institutional practices espoused by the leader (or loci playing the role of the leader) predict the organizational outcomes.

Proposition 5: The context moderates the effect of EEL on the organizational outcomes.

Chic-fil-A is one of the organizations, to a higher degree, that has modelled the ethical and effective leadership. Chic-fil-A's leadership model is based on five pillars abbreviated as SERVE, which stand for See the future (Institutional practices), Engage and develops other (People practices), Reinvent continuously (Institutional practices), Value results (Outcomes) and relationships (People practices) and Embody values (Character) (Miller, 2012). The only domain of EEL model that cannot be identified directly from Chic-fil-A model is characteristics; nevertheless, there is plenty to learn from Chic-fil-A on leadership.

\subsection{The EEL Subdomains}

The six domains of EEL model are made up of numerous sub-domains or aspects. This paper does pretend to offer an exhaustive list of all the aspects the 
make up each of the domains, however, a few aspects are captured in Figure A2 in Appendix. It is author's proposition that the required aspects of a given leadership situation may vary depending on the situation but the six domains of leadership remain the same.

A genius leader is not the one who is endowed in all the aspects of each of the six domains but the one who is able to switch among the aspects of the different domains as the situation may demand. In ethical and effective leadership model, leadership styles can still be realized through combinations of aspects from one domain or different domains. Whereas leadership styles, as they are conceptualized in the existing leadership literature, are traceable predominantly in the domains of people practices and institutional practices, it is the author's contention that for such styles to be beneficial, the leaders who practice them must embody character, be cognizant of the context and aim at outcomes that benefit all the stakeholders.

\subsection{Leadership Development}

Empirical evidence shows that the variation in leadership is explained by 30 percent genetics and 70 percent nurture (Avolio, Walumbwa, \& Weber, 2009). Scholars and practitioners alike must recalibrate their intentions and reasons for the search of definitive definition or prediction of who is a leader. The intentions must not be based on yesteryears' notion that leaders are born rather than developed (made). Leaders are not stationed somewhere waiting to be discovered. Leadership developers should seek for potentials so that they can develop them into the leaders they desire.

Despite the vital role played by leadership across different spheres of the society, numerous scholars argue that extant leadership development literature is shallow on leadership development theories (Snook et al., 2012; Day, Fleenor, Atwater, Sturm, \& Mckee, 2014; Volz-Peacock, Carson \& Marquardt, 2016). It is the author's understanding that leadership development is learning what leadership is and how to lead, particularly how to be an ethical and effective leader. On the surface of it can be argued that leadership development is made up of two components. First, the conceptualization of leadership, particularly the leadership components. Second, the how, which covers the length of the program, the delivery modes, the evaluation of leadership development, when who and where to conduct the leadership development. The latter does not need the reinvention of the wheel, it can be solved by borrowing wisely from the works of learning scholars and psychologist like Knowles, Holton III, Swanson (1998); Kegan (1982; 1994); Kolb (1984); Bandura (1977); Kirkpatrick (1998). This paper attempts to offer a solution to the former challenge, by defining the leadership components/domains. EEL is a good starting point for leadership development since it postulates on the six domains that make up leadership. Figure A3 in Appendix shows EEL model for scholars and students, which cover the content of leadership development. 
A deeper look at leadership development, particularly impactful leadership development will reveal a third challenge that is both a leadership development challenge and challenge across several fields. Human resource developers are still hoping for a substantial improvement in employees' performance after numerous insightful pieces of training, Kivland \& King (2015); the clerics are puzzled why their congregation behaves the same after 100s of sermons, academic conference organizers are eagerly awaiting to see academic awakening in millions who attended conferences worldwide. The disappointing results lead stewards, particularly scholars and developers, to search deep into themselves, to develop better programs, to revamp program delivery mechanisms. The stewards also ask for more theories constantly, but the more they receive the more they ask for the next dose. It is understandable, stewards have a part to play in shepherding the next crop of leaders but how long shall it take for the stewards to admit that the current approach isn't working, and return the ball in the students' court while acknowledging that they cannot make them leaders but they can help them on their journey.

Despite what leaders are taught or not, the decision to lead remains theirs, and for continued impact, the decisions have to be made daily. A person who has made up her mind to lead, even if she lacks the right leadership theory she will find a way to get it. Stewards should seek ways to help leaders choose to lead daily. The pursuit of answers to this question may be the missing ingredient in the leadership cuisines. Leadership scholars and practitioners have spent too much energy, for too long, asking and answering the same question: what/how can we teach leaders to lead better? Going forward the central question should be, how do we inspire leaders to choose to lead daily? This is a subject of another paper I am writing (Beyond Leadership). The current paper wants to tie the existing loose ends in the former questions as a signal for leadership fraternity that our work is done in that arena we need to expand the leadership territory to include the latter question.

\subsection{The Leadership Definition}

According to Kellerman (2012), there are over 1500 definition of leadership. Despite the arguments by Grint (2005) and Gabriel (2015) that we should live with the paradoxes or ambiguities that exist in definitions of leadership, I think an attempt to eliminate the paradoxes is one more paradox that we can live with. There is a need to reclaim the word leadership from Milosevic and Jezebel so that the mention of leadership automatically brings in memories of Martin Luther King or Mother Theresa. After all, inept leadership is not leadership. Alternatively, every time we talk about leadership we have to be specific whether we are talking about good (ethical and effective) leadership or we are talking about bad (unethical and ineffective) leadership. Kellerman (2004) defines bad leadership as unethical and ineffective leadership while Gardner (2011) defines bad leadership as poor and ineffective leadership. The dual conceptualization of 
leadership is cumbersome, but for the purposes of clarity, this paper will adopt a definition of leadership that is based on duality. Kellerman (2012) asserts that good leaders are both ethical and effective. First, here are some of the common definitions of a leader and leadership.

"Leadership is a process whereby an individual influence a group of individuals to achieve a common goal" (Northouse, 2016: p. 6).

A leader is a person who "by word and/or personal example, markedly influence the behaviours, thoughts, and/or feelings of a significant number of their fellow human beings" Gardner (2011).

"The only definition of a leader is someone who has followers" (Drucker, 1996: p. 54).

"Leadership is influence, nothing more or less" (Maxwell, 1998: p. 3).

The above definitions of leadership can apply to Martin Luther King as well as Slobodan Milošević, both were leaders who influenced several groups of followers to achieve common goals. This is a problem, I think when we are developing leaders especially through leadership education we ought to be clear whether we are developing a future Martin Luther King or Slobodan Milošević. I think leadership is the only field that defines the angels' work and the devil's work similarly. It should be made clear who is being multiplied, Jezebel or Mother Theresa. If leadership is influence, are people pleased by the influence of Hitler or Idi Amin? If not there must be something more central to leadership than influence or if influence has to remain at the heart of leadership then one has to be categorical on which influence she or he is referring to.

The world is not looking for any influence, it is looking for ethical and effective influence: ethical and effective leadership. Drouillard and Kleiner assert that leadership is not only about influence and effectiveness, Hitler was good at both, yet his leadership is not worth emulating. Leadership that is worth pursuing must be built on and in morality or ethics. Drouillard and Kleiner further define moral or good leadership as, "the influencing of others, by means of reason and inclusion, to achieve organizational goals that are in the long-term best interest of all involved, with the wellbeing of society in mind" (Drouillard \& Kleiner, 1996: p. 30). Gardner (2011) argues that for the good of humanity and planet, deliberate effort must be made to increase good leaders, people who are dedicated to the pursuit of ethical ends. Borrowing from Northouse (2016) and Kellerman (2012) to answer the question of our time: what is good (ethical and effective) leadership? Ethical and effective leadership (EEL) is a process whereby ethical individual influences a group of ethical individuals to achieve common goals for the benefit of all stakeholders.

If a corrupt (definitely, unethical) leader build a permanent road for his followers, the product is ethical and the leader is effective, does it matter whether she is ethical or not? It is worth to note that unethical people love to imitate ethical people, and the test of their actions is in longevity and consistency of their acts, not in one-off deed. The products of fraudulent individuals are likely to be fraudulent unless she can cheat herself in producing something she disagrees 
with in order to hoodwink her followers so that she can live to cheat them another day. One has to look beyond the action into the doer of the action and the motives and the consistency of the action in order to identify and embrace ethical and effective leadership. Ethical and effective leadership is not a show business, it is from the heart of the leader to the hearts of the followers.

\section{Implications}

In identifying, selecting, developing and practising leadership, organizations should take into consideration context (environment) and not just situation.

The person or group of persons (leader or followers) carrying out the duties/roles of a leader should embody the six domains of EEL model. Whereas a person or group of persons may have strength in one or two domains, he must ensure that the other domains are covered in any given leadership situation.

EEL constitutes the foundation of leadership development, particularly, it provides the components of leadership.

The underlying structure of leadership revealed by EEL model offers a basis of leadership evaluation.

Leadership outcomes should be at the centre of every leadership endeavour.

Empirical research should be carried out to test the model, establish its completeness or otherwise, and if proven, then future leadership research should be guided by the model.

Some of the areas for further study include but not limited to do all the domains have equal importance? In developing leaders/leadership, are the domains learnt in a sequence or simultaneous?

\section{Conclusion}

The six foundational domains of leadership are character, characteristics, people practices, institutional practices, context and outcomes. The aim of this paper was not to pin down the ultimate combinations of leadership subdomains or aspects but to expose leadership underlying structure. Different leaders will succeed in different leadership context by emphasizing different aspects of the six leadership domains.

\section{References}

Aguilar, F. (1967). Scanning the Business Environment. New York: Macmillan.

Akella, D. (2009). Satyagraha: The Gandhian Philosophy of Conflict Management. Workplace Rights, 14, 503-523. https://doi.org/10.2190/WR.14.4.g

Allio, R. (2012). Leaders and Leadership-Many Theories, But What Advice Is Reliable? Strategy \& Leadership, 41, 4-14.

Amanchukwu, R., Stanley, G., \& Ololube, N. (2015). A Review of Leadership Theories, Principles and Styles and Their Relevance to Educational Management. Management, 5, 6-14. https://doi.org/10.1108/10878571311290016

Armstrong, M. (2006). A Handbook of Human Resource Management Practice. London: Kogan Page. 
Avolio, B., Walumbwa, F., \& Weber, T. (2009). Leadership: Current Theories, Research, and Future Directions. Annual Review of Psychology, 60, 421-449. https://doi.org/10.1146/annurev.psych.60.110707.163621

Bandura, A. (1977). Social Learning Theory. Eaglewood Cliffs, NJ: Prentice-Hall.

Bass, B. (1985). Leadership and Performance beyond Expectations. New York: Free Press.

Bass, B., Avolio, B., Jung, D., \& Berson, Y. (2003). Predicting Unit Performance by Assessing Transformational and Transactional Leadership. Journal of Applied Psychology, 88, 207-218. https://doi.org/10.1037/0021-9010.88.2.207

Becker, G. (2013). The Competitive Edge of Moral Leadership. In S. Rothlin, \& P. Haghirian (Eds.), Dimensions of Teaching Business Ethics in Asia. Berlin, Heidelberg: Springer, 9-28. https://doi.org/10.1007/978-3-642-36022-0_2

Blackmore, J. (2011). Leadership in Pursuit of Purpose: Social, Economic and Political Transformation. Transformative Leadership: A Reader, 409, 21-36.

Blake, R., \& Mouton, J. (1964). The Managerial Grid: The Key to Leadership Excellence. Houston, TX: Gulf Publishing Company.

Bredeson, P., Klar, H., \& Johansson, O. (2011). Context-Responsive Leadership: Examining Superintendent Leadership in Context. Education Policy Analysis Archives, 19, 1-28. http://epaa.asu.edu/ojs/article/view/739 https://doi.org/10.14507/epaa.v19n18.2011

Burns, J. (1978). Leadership. New York: Harper \& Row.

Carlyle, T. (1841). On Heroes, Hero-Wo and the Heroic in History. London: James Fraser.

Carsten, M., Uhl-Bien, M., West, B., Patera, J., \& McGregor, R. (2010). Exploring Social Constructions of Followership: A Qualitative Study. The Leadership Quarterly, 21, 543-562. https://doi.org/10.1016/j.leaqua.2010.03.015

Choi, S., \& Schnurr, S. (2014). Exploring Distributed Leadership: Solving Disagreements and Negotiating Consensus in a "Leaderless" Team. Discourse Studies, 16, 3-24. https://doi.org/10.1177/1461445613508891

Collins, J. (2001). Good to Great: Why Some Companies Make the Leap and Others Don't. New York: William Collins.

Dansereau, F., Seitz, S., Chiu, C., Shaughnessy, B., \& Yammarino, F. (2013). What Makes Leadership, Leadership? Using Self-Expansion Theory to Integrate Traditional and Contemporary Approaches. The Leadership Quarterly, 24, 798-821. https://doi.org/10.1016/j.leaqua.2013.10.008

Day, D., Fleenor, J., Atwater, L., Sturm, R., \& Mckee, R. (2014). Advances in Leader and Leadership Development: A Review of 25 Years of Research and Theory. The Leadership Quarterly, 25, 63-82. https://doi.org/10.1016/j.leaqua.2013.11.004

DeRue, S., Nahrgang, J., Wellman, N., \& Humphrey, S. (2011). Trait \& Behavioural Theories of Leadership: An Integration \& Meta-Analytic Test of Their Relative Validity. Personnel Psychology, 64, 7-52. https://doi.org/10.1111/j.1744-6570.2010.01201.x

Dinh, J., Lord, R., Gardner, W., Meuser, J., Liden, R., \& Hu, J. (2014). Leadership Theory and Research in the New Millennium: Current Theoretical Trends and Changing Perspectives. Leadership Quarterly, 25, 36-62. https://doi.org/10.1016/j.leaqua.2013.11.005

Drouillard, S., \& Kleiner, B. (1996). Good Leadership, Management Development Review, 9, 30-33. https://doi.org/10.1108/09622519610131554

Drucker, P. (1996). Your Leadership Is Unique. Good News: There Is No One Leadership 
Personality. Christianity Today International/Leadership Journal, 17, 54-55.

Drucker, P. (2004). Peter Drucker on Leadership. https://www.forbes.com/2004/11/19/cz_rk_1119drucker.html

Eberly, M., Johnson, M. Hernandez, M., \& Avolio, B. (2013). An Integrative Process Model of Leadership: Examining Loci, Mechanisms, and Event Cycles. American Psychological Association, 68, 427-443. https://doi.org/10.1037/a0032244

Fiedler, F. (1967). A Theory of Leadership Effectiveness. New York: McGraw-Hill.

Flanigan, J. (2017). Philosophical Methodology and Leadership Ethics. Leadership, 1-24. https://doi.org/10.1177/1742715017711823

Gabriel, Y. (2015). The Caring Leader-What Followers Expect of Their Leaders and Why? Leadership, 11, 316-334. https://doi.org/10.1177/1742715014532482

Gardner, H. (2011). Leading Minds: An Anatomy of Leadership. New York: Basic Book.

Garsombke, D. (1989). International Competitor Analysis. Planning Review, 17, 42-47. https://doi.org/10.1108/eb054260

George, B. (2003). Authentic Leadership: Rediscovering the Secrets to Creating Lasting Value. San Francisco, CA: Jossey-Bass.

Glynn, M., \& Raffaelli, R. (2010). Uncovering Mechanisms of Theory Development in an Academic Field: Lessons from Leadership Research. The Academy of Management Annals, 4, 359-401. https://doi.org/10.1080/19416520.2010.495530

Gomienchi, S. (2004). Trust and Leadership. Political Science, 56, 27-38.

Greenleaf, R. (1970). The Servant as Leaders. Westfield, ID: Greenleaf Centre for Servant Leadership.

Grint, K. (2005). Leadership: LIMITS and Possibilities. New York: Palgrave Macmillan.

Hambrick, D., \& Mason, P. (1984). Upper Echelons: The Organization as a Reflection of Its Top Managers. The Academy of Management Review, 9, 193-206.

Handy, C. (1994). The Age of Paradox. Boston, MA: Harvard Business School Press.

Hartley, J., \& Benington, J. (2010). Leadership for Healthcare. Bristol, UK: The Policy Press, University of Bristol. https://doi.org/10.1332/policypress/9781847424877.001.0001

Hawker, N., \& Edmonds, T. (2014). Strategic Management Concepts for Antitrust: Cooperation, Stakeholders and Sustainability. The Antitrust Bulletin, 59, 769-788. https://doi.org/10.1177/0003603X1405900404

Heifetz, R. (1994). Leadership without Easy Answers. Cambridge, MA: Belknap Press.

Hernandez, M., Eberly, M., Avolio, B., \& Johnson, M. (2011). The Loci and Mechanisms of Leadership: Exploring a More Comprehensive View of Leadership Theory. The Leadership Quarterly, 22, 1165-1185. https://doi.org/10.1016/j.leaqua.2011.09.009

Hersey, P., \& Blanchard, K. (1977). Management of Organizational Behaviour: Utilizing Human Resource. Englewood Cliffs, NJ: Prentice Hall.

Hill, S. (2016). Team leadership. In P. Northouse (Ed.), Leadership: Theory and Practice (7th ed., pp. 363-396). Thousand Oaks, CA: Sage.

Hill, T., \& Westbrook, R. (1997). SWOT Analysis: It's Time for a Product Recall. Long Range Planning, 30, 46-52. https://doi.org/10.1016/S0024-6301(96)00095-7

House, R. (1976). A 1976 Theory of Charismatic Leadership. University of Toronto, Faculty of Management Studies, 77, 1-34.

House, R., \& Aditya, R. (1997). The Social Scientific Study of Leadership: Quo Vadis? Journal of Management, 23, 409-473. https://doi.org/10.1177/014920639702300306 
House, R., \& Mitchell, R. (1974). Path-Goal Theory of Leadership. Journal of Contemporary Business, 9, 81-98.

Huang, L., \& Paterson, T. (2017). Group Ethical Voice: Influence of Ethical Leadership and Impact on Ethical Performance. Journal of Management, 43, 1157-1184. https://doi.org/10.1177/0149206314546195

Ireland, R., \& Hitt, M. (2005). Achieving and Maintaining Strategic Competitiveness in the 21st Century: The Role of Strategic Leadership. Academy of Management Executive, 19, 63-78. https://doi.org/10.5465/AME.2005.19417908

Išoraitè, M. (2009). Importance of Strategic Alliances in Company's Activity. Intellectual Economics, 1, 39-46.

Janiesch, C. (2010). Situation vs. Context: Considerations on the Level of Detail in Modelling Method Adaptation. Proceedings of the 43rd Hawaii International Conference on System Sciences. Koloa, Kauai, Hawaii: IEEE Computer Society. https://doi.org/10.1109/HICSS.2010.340

Jeyaraj, K., Muralidharan, C., Senthilvelan, T., \& Deshmukh, S. (2014). Customer Needs and Customer Satisfaction Analysis in a Textile Dyeing Process: A Case Study. Clothing and Textiles Research Journal, 32, 282-295. https://doi.org/10.1177/0887302X14546362

Jindal, D., Jee, C., \& Thakur, R. (2011). Nissan: Go-Global Strategy. Business Strategy Series, 12, 195-201. https://doi.org/10.1108/17515631111155151

Johnson, G., Whittington, R., Scholes, K., Angwin, D., \& Regner, P. (2014). Exploring Strategy: Text and Cases. New York: Pearson.

Judge, T., Bono, J., Ilies, R., \& Gerhardt, M. (2002). Personality and Leadership: A Qualitative and Quantitative Review. Journal of Applied Psychology, 87, 765-780. https://doi.org/10.1037/0021-9010.87.4.765

Katz, L. (1955). Skills of an Effective Administrator. Harvard Business Review, 33, 33-42.

Kegan, R. (1982). The Evolving Self: Problem and Process in Human Development. Cambridge, MA: Harvard University Press.

Kegan, R. (1994). In over Our Heads: The Mental Demands of Modern Life. Cambridge, MA: Harvard University Press.

Kellerman, B. (2004) Bad Leadership: What It Is, How It Happens, Why It Matters. Boston, MA: Harvard Business School Press.

Kellerman, B. (2008). Followership: How Followers Are Creating Change and Changing Leaders. Boston, MA: Harvard Business School.

Kellerman, B. (2012). The End of Leadership. New York: Harper Collins.

Kellerman, B. (2015). Hard Times: Leadership in America. Stanford, CA: Stanford University Press.

Kellner, D. (2007). The Katrina Hurricane Spectacle and Crisis of the Bush Presidency. Cultural Studies: Critical Methodologies, 7, 222-234. https://doi.org/10.1177/1532708606295642

Kets de Vries, M., \& Cheak, A. (2016). Psychodynamic Approach. In P. Northouse (Ed.), Leadership: Theory and Practice (7th ed., pp. 363-396). Thousand Oaks, CA: Sage.

Kirkpatrick, D. (1998). Evaluating Training Programs: The Four Levels. San Francisco, CA: Berrett-Koehler.

Kirkpatrick, S., \& Locke, E. (1991). Leadership: Do Traits Matter? The Executive, 5, 48-60. https://doi.org/10.5465/AME.1991.4274679

Kivland, C., \& King, N. (2015). Six Reasons Why Leadership Training Fails. Leadership 
Excellence Essentials Presented by HR.com. http://www.learningexecutive.com/CLLC/2015/2015LECoverStory-SixReasonsWhyLea dershipTrainingFails_AResearchReview.pdf

Knowles, M., Holton III, E., \& Swanson, R. (1998). The Adult Learner: The Definitive Classic in Adult Education and Human Resource Development. San Diego, CA: Elsevier.

Kolb, D. (1984). Experiential Learning: Experience as the Source of Learning and Development. Englewood Cliffs, NJ: Prentice-Hall.

Kotter, J. (2012). Leading Change. Boston, MA: Harvard Business Review Press.

Kouzes, J., \& Posner, B. (2012). The Leadership Challenges: How to Make Extraordinary Things Happen in Organizations. San Francisco, CA: The Leadership Challenge-A Willy Brand.

Lawler, J. (2005). The Essence of Leadership? Existentialism and Leadership. Leadership, 1, 215-231. https://doi.org/10.1177/1742715005051860

Leavy, B. (2003). Understanding the Triad of Great Leadership-Context, Conviction and Credibility. Strategy \& Leadership, 31, 1-8. https://doi.org/10.1108/sl.2003.26131aab.001

Leidner, G. (2017). The Leadership Secrets of Hamilton: 7 Steps to Revolutionary Leadership from Alexander Hamilton and the Founding Fathers. Naperville, IL: Simple Truth.

Lunenburg, F. (2010). Leader-Member Exchange Theory: Another Perspective on the Leadership Process. International Journal of Management, Business, and Administration, 13, 1-5.

Luthans, F., \& Avolio, B. (2003). Authentic Leadership: A Positive Developmental Approach. In K. S. Cameron, J. E. Dutton, \& R. E. Quinn (Eds.), Positive Organizational Scholarship: Foundations of a New Discipline, 241-258.

Madison, K., Holt, D., Kellermanns, F., \& Ranft, A. (2016). Viewing Family Firm Behaviour and Governance through the Lens of Agency and Stewardship Theories. Family Business Review, 29, 65-93. https://doi.org/10.1177/0894486515594292

Manz, C., \& Sims, H. (1991). Super Leadership: Beyond the Myth of Heroic Leadership. Organizational Dynamics, 19, 18-35. https://doi.org/10.1016/0090-2616(91)90051-A

Maxwell, J. (1998). The 21 Irrefutable Laws of Leadership: Follow Them and People Will Follow You. Nashville, TN: Thomas Nelson Publishers.

Meuser, J., Gardner, W., Dinh, J., Hu, J., Liden, R., \& Lord, R. (2016). A Network Analysis of Leadership Theory: The Infancy of Integration. Journal of Management, 42, 1374-1403. https://doi.org/10.1177/0149206316647099

Mihelič, K., Lipičnik, B., \& Tekavčič, M. (2010). Ethical Leadership. International Journal of Management \& Information Systems, 14, 31-42. https://doi.org/10.19030/ijmis.v14i5.11

Mikkelsen, K., \& Jarche, H. (2015). The Best Leaders Are Constant Learners. Harvard Business Review. https://hbr.org/2015/10/the-best-leaders-are-constant-learners

Miller, M. (2012). The Secrets: What Great Leaders Know and Do. (J. Mellado, Interviewer.) https://www.youtube.com/watch?v=obdzWZG1yRE\&t=75s

Morris, R. (2014). Constructions of Following from a Relational Perspective: A Follower-Focused Study. Journal of Leadership Education, 2014, 51-62.

https://doi.org/10.12806/V13/I4/C7

Murnieks, C., Mosakowski, E., \& Cardon, M. (2014). Pathways of Passion: Identity Cen- 
trality, Passion, and Behaviour among Entrepreneurs. Journal of Management, 40, 1583-1606. https://doi.org/10.1177/0149206311433855

Nixon, R. (1982). Leaders. London: Sidgwick and Jackson.

Northouse, P. (2016). Leadership Theory and Practice. Thousand Oaks, CA: Sage.

Novicevic, M., Zikic, J., Martin, J., Humphreys, J., \& Roberts, F. (2013). Responsible Executive Leadership: A Moral-Identity Analysis Based on Barnard's Conceptualization. Journal of Management History, 19, 474-491. https://doi.org/10.1108/JMH-10-2011-0030

Petrie, N. (2014). Future Trends in Leadership Development. Greensboro, NC: Center for Creative Leadership.

Porter, M. (1985). Competitive Advantage: Creating and Sustaining Superior Performance. New York: The Free Press.

Porter, M. (2008). The Five Competitive Forces That Shape Strategy. Harvard Business Review, 86, 79-93.

Rahim, M. (2002). Toward a Theory of Managing Organizational Conflict. International Journal of Conflict Management, 13, 206-235. https://doi.org/10.1108/eb022874

Rao, A. (2016). From Brand to Customer. Journal of Creating Value, 2, 18-30. https://doi.org/10.1177/2394964315627253

Rothlin, S., \& Haghirian, P. (2013). Dimensions of Teaching Business Ethics in Asia. London: Springer. https://doi.org/10.1007/978-3-642-36022-0

Russell, E., \& Underwood, C. (2016). Exploring the Role of Purpose in Leadership. HR Magazine.

http://www.hrmagazine.co.uk/article-details/exploring-the-role-of-purpose-in-leadersh ip

Safty, A. (2003). Moral Leadership: Beyond Management and Governance. Harvard International Review, 25, 84-89.

Silva, A. (2015). An Integrated Leadership Theory. Journal of Perspectives in Organizational Behaviour, Management, \& Leadership, 1, 5-9.

Snook, S., Nohria, N., \& Khurana, R. (2012). The Handbook for Teaching Leadership: Knowing, Doing and Being. Los Angeles, CA: Sage.

Spears, L. (2002). Tracing the Past, Present, and Future of Servant-Leadership. In L. Spear, \& M. Lawrence (Eds.), Focus on Leadership: Developments in Theory and Research (pp. 1-16). New York: Palgrave Macmillan.

Spector, B. (2016). Carlyle, Freud, and the Great Man Theory More Fully Considered. Leadership, 12, 250-260. https://doi.org/10.1177/1742715015571392

Stam, H. (2007). Theoretical Psychology. In K. Pawlik, \& M. Rosenzweig (Eds.), The International Handbook of Psychology (pp. 551-569). London: Sage Publications.

Stogdill, R. (1948). Personal Factors Associated with Leadership: A Survey of the Literature. Journal of Psychology, 25, 35-71. https://doi.org/10.1080/00223980.1948.9917362

Stogdill, R. (1974). Handbook of Leadership: A Survey of Theory and Research. New York: Free Press.

Tatum, C., \& Eberlin, R. (2007). Leadership, Ethics, and Justice in Strategic Decision Making. Business Strategy Series, 8, 303-310.

https://doi.org/10.1108/17515630710684358

Thompson, L. (2010). The Global Moral Compass for Business Leaders. Journal of Business Ethics, 93, 15-32. https://doi.org/10.1007/s10551-010-0624-9 
Uhuru (2016). President Uhuru Frustrated by Corruption and Sluggishness of Agencies. https://www.youtube.com/watch?v=UXPqWuW0fGU

Volz-Peacock, M., Carson, B., \& Marquardt, M. (2016). Action Learning and Leadership Development. Advances in Developing Human Resources, 18, 318-333. https://doi.org/10.1177/1523422316645884

Vroom, V., \& Jago, A. (1988). The New Leadership: Managing Participation in Organizations. Englewood Cliffs, NJ: Prentice-Hall.

Vroom, V., \& Yetton, P. (1973). Leadership and Decision-Making. Pittsburgh, PA: University of Pittsburgh Press. https://doi.org/10.2307/j.ctt6wrc8r

Weber, M. (1947). The Theory of Social and Economic Organizations. New York: Free Press.

White, J. (1984). Strategic Planning and the Small Business. Industrial Management \& Data Systems, 84, 8-12. https://doi.org/10.1108/eb057381

Wright, P., \& McMahan, G. (1992). Theoretical Perspectives for Human Resource Management. Journal of Management, 18, 295-320. https://doi.org/10.1177/014920639201800205

Yew, L. (2000). From Third World to first: The Singapore Story, 1965-2000: Singapore and the Asian Economic Boom. New York: HarperCollins Publishers.

Zaleznik, A., \& Kets de Vries, M. (1975). Power and the Corporate Mind. Oxford: Houghton Mifflin. 


\section{Appendix}

Table A1. Summary of Leadership Theories. The content of the table is mainly developed from the theory model (the most practical part of the theory), in some cases, other defining aspects of the theory are included.

\begin{tabular}{|c|c|c|}
\hline Theory & Character & Characteristics \\
\hline $\begin{array}{l}\text { 1) Great man } \\
\text { Leaders are born and not made } \\
\text { (Carlyle, 1841, Spector, 2016). }\end{array}$ & $\begin{array}{l}\text { Leaders are } \\
\text { guided by } \\
\text { morality. }\end{array}$ & $\begin{array}{l}\text { Leaders are divinely } \\
\text { inspired } \\
\text { (charismatic), they } \\
\text { are full of wisdom } \\
\text { and they are heroic. }\end{array}$ \\
\hline $\begin{array}{l}\text { 2) Trait } \\
\text { Leaders share special } \\
\text { characteristics, it is people who } \\
\text { have those characteristics that } \\
\text { become leaders (Stogdill, 1948, } \\
\text { 1974; Kirkpatrick \& Locke, 1991). }\end{array}$ & $\begin{array}{l}\text { Leaders portray } \\
\text { integrity }\end{array}$ & $\begin{array}{l}\text { Leaders are } \\
\text { intelligent, } \\
\text { determined, sociable } \\
\text { self-confidence, } \\
\text { responsible, } \\
\text { insightful and } \\
\text { tolerant. }\end{array}$ \\
\hline
\end{tabular}

\section{3) Psychodynamic leadership}

Leaders not only know their personality types, they also know their followers and they utilize this knowledge together with the relationship with their followers to achieve the desired goals (Zaleznik \& Kets de Vries, 1975; Kets de

Vries, \& Cheak, 2016).

\section{4) Authentic leadership ( $\mathrm{AL}$ )}

According to Avolio, Walumbwa, \& Weber (2009: p. 423) AL is "transparent and ethical leader behaviour that encourages openness in sharing information needed to make decisions while accepting followers' inputs". Luthans \& Avolio (2003); George (2003) have similar conceptualization of AL to the one above.

\section{5) Skills}

Leaders require certain skills in order to be effective in their work (Katz, 1955).

\section{6) Behavioural}

Leaders need to portray certain behaviour (people and task behaviour) to achieve desired goals. One of the behavioural approaches is managerial grid, where the ultimate goal is to practice team style leadership $(9,9)$. At 9, 9 both people and tasks are highly valued,

Authentic leaders have an Authentic leaders internalized moral are self-aware, they perspective, they know there purpose, have strong values they act from their to guide them in hearts, hence, they their endeavours are passionate about and they are their missions. self-disciplined.
Leaders seek to gain insight into subordinates' psychological makeup (why do followers

Leaders are behave/act the way they self-aware do; what motivates them) in order to influence them to take actions that will lead to achieving the desired goals.

Authentic leaders have relational transparency; they maintain trusting relationship with others.

Authentic leaders undertake "balanced processing" of information.
Desired

goals
Leaders should have human skills.

Leaders are people oriented (provide conducive working conditions and employees' development).
Leaders should have technical and conceptual skills.

(Blake \& Mouton, 1964). 
7) Situational leadership

Different situations require different leadership styles

(Hersey \& Blanchard, 1977).

\section{8) Fiedler's contingency \\ leadership}

Fiedler (1967) argues that a right

leader for the right situation is

needed to achieve the desired goals.

The leader relies on least preferred

co-worker scores to predict his

potential success with a given team.

\section{9) Vroom-Yetton decision}

\section{process}

Leaders should identify the best

decision-making style for the

situation (in consideration of time

constraint, quality of the decision

and team commitment) (Vroom \&

Yetton, 1973; Vroom \& Jago, 1988).

\section{0) Level-five leadership}

Collins (2001) argues that organizations grow as leadership grows from highly capable individual to the executive (the level-5-leader).

\section{1) Adaptive leadership}

In a complex and changing world, there are increasing numbers of adaptive as opposed to technical challenges. Adaptive challenges (AC) do not have ready-made solutions. The leader relentlessly helps followers to solve the AC (Heifetz, 1994; Northouse, 2016).
The leader creates a trusting atmosphere through the holding environment.
A leader has an intense professional will/fierce resolve.
Leader's effectiveness depends on whether she has a good relationship with her team.

\section{In decision making the}

leader can be

Autocratic (A1),

Autocratic (A2),

Consultative (C1),

Consultative (C2) or

Collaborative (G1)

towards her team.

The leader finds the right people and she gives credit where it is due and asks for help.

Leader regulates distress, maintains disciplined attention, gives the work back to the people and protects leadership

Charismatic leader is a good role model and communicates high expectations to the followers.

Leaders should model the way, enable others to Leaders should inspire a act and encourage the heart. over the situation). voices from below. understanding of tasks and what it takes to accomplish the tasks.
Leaders have a clear
Leader's effectiveness depends on whether the tasks are highly structured and whether the leader's position power is high (the leader must have control

The leader either has a clear understanding of the prevailing situation or she has some understanding and she needs the team's input for better results.

Leader confronts the brutal facts, she determines the encourage a culture of discipline and encourage adoption of critical technology.

Adaptive leader gets on the balcony and identifies adaptive challenges. optimal strategic path,
Leader articulates the goals and shows competence.

\section{Northouse, 2016).} self-confident.

\section{3) Kouzes and Posner's}

leadership challenge

Extraordinary things happen in

organizations when leaders carry

out five tested leadership practices

(Kouzes \& Posner, 2012). 


\section{Continued}

\section{4) Transactional leadership}

Transactional leaders use rewards and punishment to encourage followers to accomplish organizational goals (Bass, Avolio, Jung, \& Berson, 2003).

\section{5) Leader-member exchange}

Lunenburg (2010) argues that the leadership process in LMX depends on the dyadic relationship between the leaders and members (followers) in both the in-group and out-group.

\section{6) Path-goal}

Theory advocates for alignment of leader's behaviour, followers' characteristics and task characteristics. Leader's behaviouris subject to tasks' and followers' characteristics (House \& Mitchell, 1974).

17) Transformational leadership The leader motivates followers to perform beyond expectation (to make huge changes in the organization). Both the leader and followers work together toward a higher level of productivity (Bass, 1985).

\section{8) Servant leadership}

Servant leader is a servant to his followers first and foremost. He also ensures that followers are well-equipped for their roles (Greenleaf, 1970; Spears, 2002).
Leaders agree on the performance and the reward that will accompany it (contingent reward), the leader actively search for contract/agreement breach and offer punishment (active management by exception) or the leader only steps in to punish the follower when goals are not met (passive management by exception).

Leader creates and maintains a close relationship with the in-group and the opposite is true for the out-group. The responsibilities, attention and rewards that a follower gets from the leader depending on the level of their relationship (stranger, acquaintance and partnership).

The leader motivates the followers to achieve planned goals through the following behaviour: directive, supportive, participative and achievement-oriented leadership.

Leaders offer idealized influence, inspired
High moral standards

stimulation and

individualized

consideration to their followers.
The leaders understand tasks characteristics, work environment, followers' characteristics and how to motivate them to carry out the tasks.

\section{Goals}

Performance beyond expectations
Leader is a listener, he heals, he Leader serves the empathizes with

followers with others, he is sheer humility. self-aware, he is

persuasive and he has foresight.
The leader is committed The servant leader to people's growth and conceptualizes the vision community building for the organization. 


\section{Continued}

\section{9) Team leadership}

It is a dynamic leadership: leadership can be shared, or different people can provide leadership at different times of the team tasks (Hill, 2016).

\section{0) Strategic Leadership}

Strategic leadership ensures that the firm competes effectively in the turbulent environment, not just in the present but also in the long term (Ireland \& Hitt, 2005).

\section{1) Ethical leadership} Ethical leadership is guided by moral values or universally accepted principles (Mihelič, Lipičnik \& Tekavčič, 2010; Northouse, 2016).

\section{2) Upper echelon}

Why do organizations behave the way they do? The top executives (upper echelon) make company after its own image; what we see in organizations is as a result of executives' characteristics (Hambrick \& Mason, 1984).

Leader fulfils relational roles e.g. managing conflicts and environmental roles e.g. networking.

Leader helps with emphasizing ethical practice.

Leaders set ethical standards and ethics governs decision making. They respect others, show justice and value honest.
Leader helps with exploiting and maintaining core competencies and developing human capital.

Leaders model behaviour for followers, they explain to followers why they made certain decisions, serve others, and build community.
Team

Leaders fulfils the task roles e.g. goal focusing. performance and development.

Leader helps with determining strategic direction, establishing balanced organizational controls and sustaining an

Effective strategic leadership effective organizational culture.
Leaders'

characteristics can be psychological like cognitive base value or observable like age.
Leaders make strategic choices like product innovation and acquisition.
Variability in profitability, growth and survival.

Table A2. Environment/Context analysis.

\begin{tabular}{|c|c|c|c|c|c|c|}
\hline \multirow[b]{2}{*}{ Internal Environment } & \multicolumn{6}{|c|}{ External Environment } \\
\hline & $\begin{array}{l}\text { General Business } \\
\text { Environment }\end{array}$ & Industry & Competitor & Customers & $\begin{array}{c}\text { Collaborators } \\
\text { (Partners, } \\
\text { Alliances) }\end{array}$ & Stakeholders \\
\hline $\begin{array}{l}\text { 1) Strength (organizational } \\
\text { resources \& capabilities) } \\
\text { 2) Weakness } \\
\text { 3) Performance } \\
\text { 4) Vision, mission and } \\
\text { strategies } \\
\text { 5) Climate and Culture } \\
\text { 6) History } \\
\text { (Hill \& Westbrook, 1997; } \\
\text { White, 1984; Johnson, } \\
\text { Whittington, Scholes, } \\
\text { Angwin, \& Regner, 2014) }\end{array}$ & $\begin{array}{l}\text { 1) Political/legal } \\
\text { 2) Economic } \\
\text { 3) Social } \\
\text { 4) Technological } \\
\text { 5) Ecological } \\
\text { 6) Demographic } \\
\text { 7) Global } \\
\text { (Aguilar, 1967; } \\
\text { Porter, 1985; Jindal, } \\
\text { Jee, \& Thakur, 2011) }\end{array}$ & $\begin{array}{l}\text { 1) Threat of new } \\
\text { entrants } \\
\text { 2) Power of } \\
\text { suppliers } \\
\text { 3) Power of buyers } \\
\text { 4) Threat of product } \\
\text { substitutes } \\
\text { 5) Intensity of } \\
\text { rivalry among } \\
\text { competitors } \\
\text { (Porter, 2008) }\end{array}$ & $\begin{array}{l}\text { 1) Long medium } \\
\text { and short-term } \\
\text { objectives } \\
\text { 2) Current and } \\
\text { future strategies } \\
\text { 3) Strengths and } \\
\text { weaknesses } \\
\text { 4) Market share } \\
\text { 5) Positioning } \\
\text { (Porter, 1985; } \\
\text { Garsombke, 1989) }\end{array}$ & $\begin{array}{l}\text { 1) Market size } \\
\text { 2) Market growth } \\
\text { 3) Wants and needs } \\
\text { 4) Demographic } \\
\text { 5) Motivation to } \\
\text { buy } \\
\text { (Jeyaraj, } \\
\text { Muralidharan, } \\
\text { Senthilvelan, \& } \\
\text { Deshmukh, 2014; } \\
\text { Rao, 2016) }\end{array}$ & $\begin{array}{l}\text { 1) Strengths and } \\
\text { weaknesses } \\
\text { 2) Performance } \\
\text { (Išoraitè, 2009) }\end{array}$ & $\begin{array}{l}\text { 1) Wants and } \\
\text { needs } \\
\text { 2) Level of } \\
\text { influence } \\
\text { (Hawker \& } \\
\text { Edmonds, 2014) }\end{array}$ \\
\hline
\end{tabular}




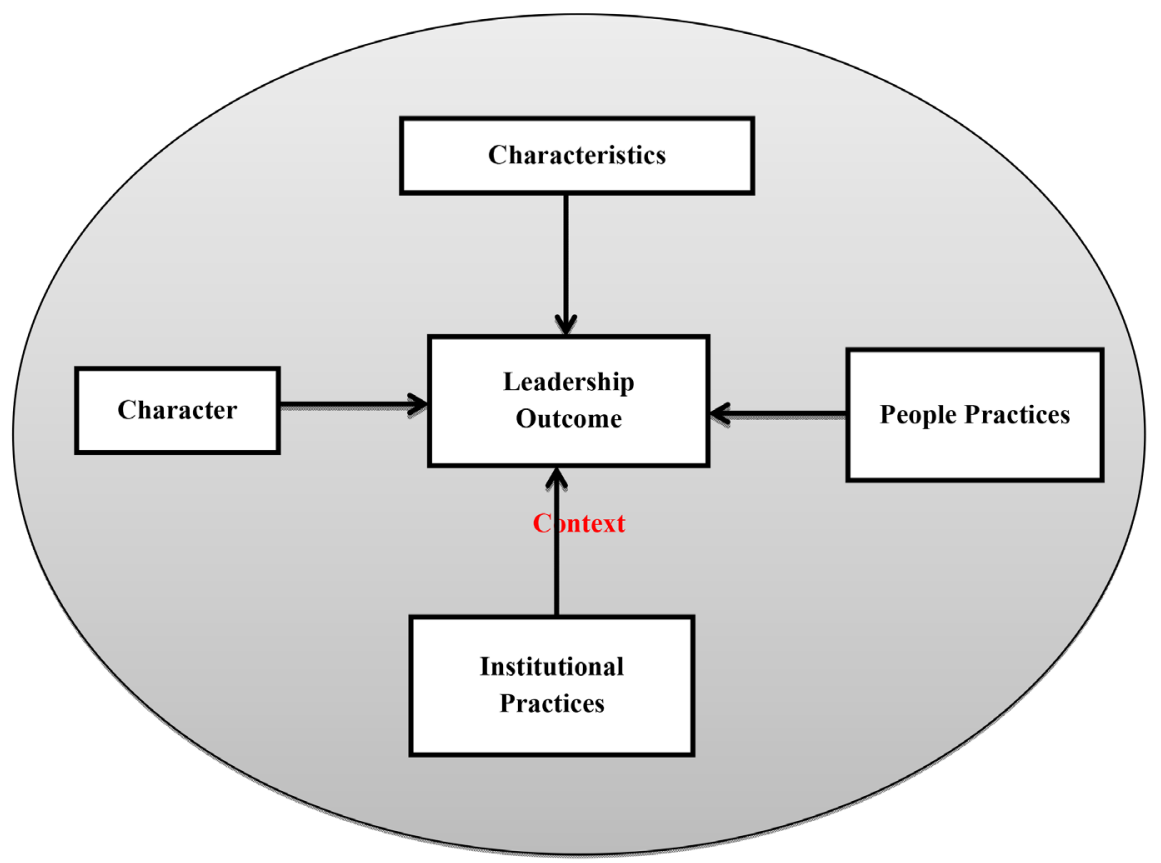

Figure A1. EEL model for leadership practitioners. 
1. Honesty (Rothlin \& Haghirian, 2013)

\section{Character}

2. Trustworthiness (Dansereau et al, 2013; Thompson, 2010)

3. Integrity (Drouillard \& Kleiner, 1996)

4. Humility (Collins, 2011))

5. Stewardship (Novicevic et al., 2013)

6. Accountability (Safty, 2003)

7. Responsibility (Safty, 2003; Novicevic et al., 2013)

8. Fairness (Mihelič, Lipičnik, \& Tekavčič, 2010)

9. Justice

10. Respect (Tatum \& Eberlin, 2007))

\begin{tabular}{|ll|}
\hline & Characteristics \\
1. Intelligence & 8. Self-regulation \\
2. Self-confidence & 9. Social skills (Goleman, 1998) \\
3. Persistence (Stogdill, 1948) & 10. Adaptability to handle change (Heifetz, 1994) \\
4. Conscientiousness & 11. Passionate (Murnieks et al., 2014) \\
5. Openness to experience & 12. Forward-looking/visionary (Ireland \& Hitt, 2005) \\
6. Extraversion (Judge et al., 2002) & 13. Learning agility (Mikkelsen \& Jarche, 2015) \\
7. Self-awareness & 14. Innovative/creative (Bass, 1985)
\end{tabular}

1. Supporting

2. Directing (House \& Mitchell, 1974)

3. Manage Conflicts (Rahim, 2002)

4. Maintain disciplined attention

. Regulate distress (Heifetz, 1994)

6. Being a good role model

7. Encourage the heart

8. Enable others to act (Kouzes \& Posner, 2012)

\section{People Practices}

9. Monitor and evaluate performance

10. Selecting and positioning people (Miller, 2012)

11. Developing human capital (Ireland \& Hitt, 2005)

12. Involve people (House \& Mitchell, 1974)

13. Communicate, include communicating goals (Kotter, 2012)

14. Motivate people to make personal sacrifice (Bass, 1985)

15. Practice relational transparency (Luthans \& Avolio, 2003)
Leadership Outcome

1. Fulfilled and equipped employees (Bass, 1985)

2. Sustainable and reasonable returns for shareholders (Madison et al., 2016)

3. Fulfilled stakeholders (consumers, government, community/society, suppliers, partners, creditors) (Greenleaf, 1970)

1. Create a sense of purpose (George, 2003)

\section{Institutional Practices}

2. Challenge the process

3. Inspire a shared vision (Kouzes \& Posner, 2012)

4. Create and sustain effective ethical culture

5. Create strategies (Ireland \& Hitt, 2005)

6. Identifies adaptive challenges (Heifetz, 1994)

7. Balanced processing of information (Luthans \& Avolio, 2003)

8. Create structures

9. Create processes (Amanchukwu, Stanley, \& Ololube, 2015)

10. Anticipate and mitigate future occurrences (Kotter, 2012; Bass, 1985)

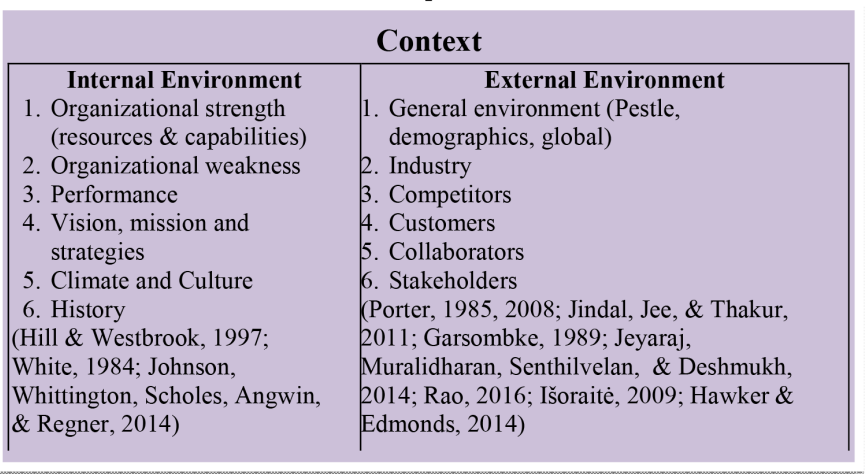

Figure A2. Selected subdomain. 


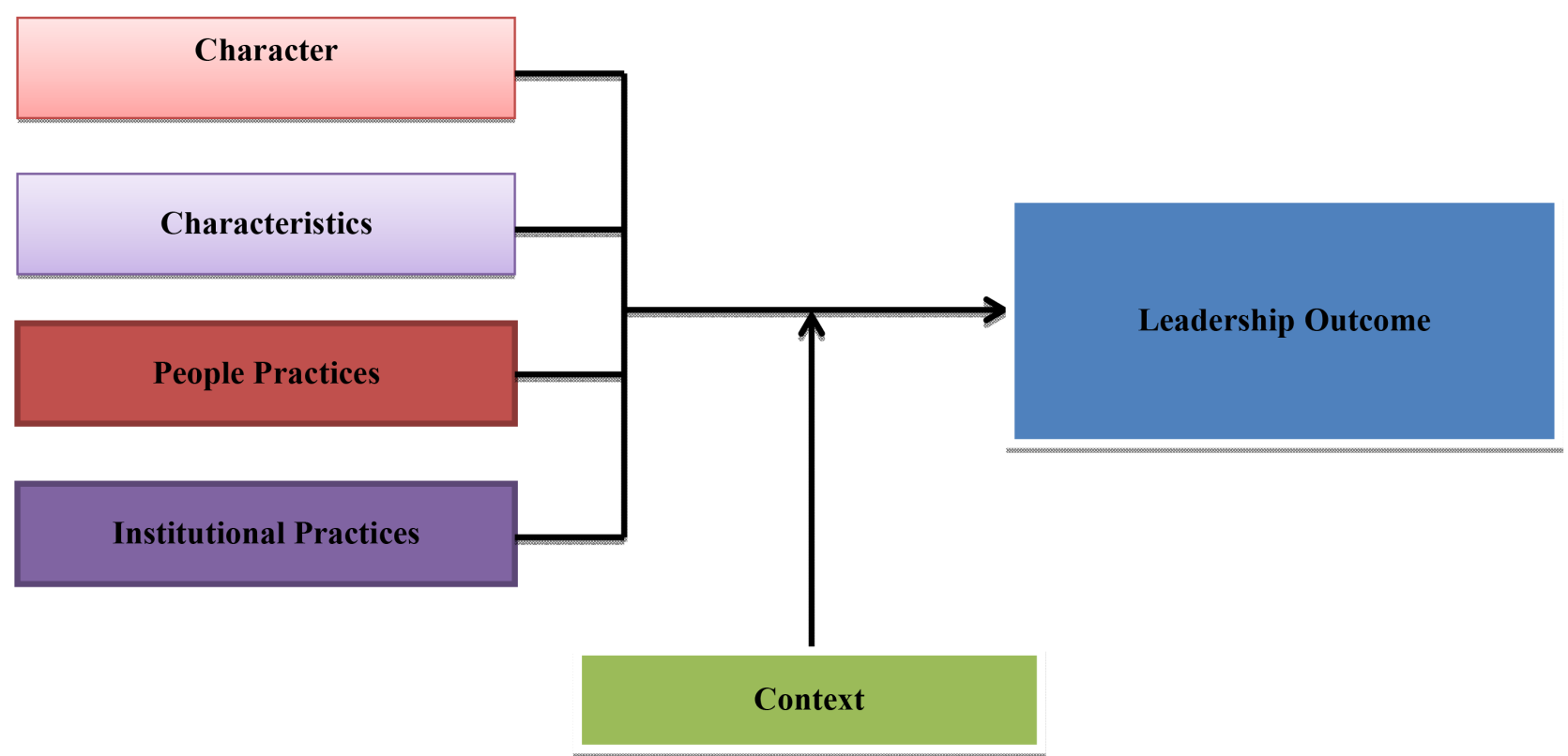

Figure A3. EEL model for leadership scholars/students. 